\title{
USE OF AGROBIODIVERSITY AND CROP MANAGEMENT PRACTICES FOR CLIMATE CHANGE ADAPTATION IN HIGH HILL AGRICULTURE OF NEPAL
}

\author{
Yuga N. Ghimire1, Ram B. Rana, Shanti Ale, Indra Poudel and Bir B. Tamang
}

\begin{abstract}
This paper highlights the effects of climate related hazards in crops and the existing adaptation pratices in the high hills of Nepal. First, interaction meeting held in Kathmandu decided to select three districts: Humla, Kaski and Solukhumbhu as the representative districts. Second, stakeholder interaction meetings held in respective districts selected three villages: Chhipra from Humla district, Lumle from Kaski district and Takashindu from Solukhumbhu district. Information was acquired using Focus Group Discussion with the use of diversity analysis tools viz. four-cell analysis, noting traits of local crop genetic resources, and matrix ranking of crop varieties. The study found that climate hazards were increasing in recent years affecting farming adversely. Existing adaptation practices included change of crops and cropping pattern and use of alternate crop management strategies. Tourism, low social value attached to traditional crops, inadequate research, and food subsidy and other forms of external support have been identified as the threat to agrobiodiversity conservation in high hills of Nepal. Promotion of agro-tourism, identifying crop varieties tolerant to extreme weather events and their promotion through technology development and value addition have been suggested to combat climate change effects in high hill agriculture in the country.
\end{abstract}

Key words: adaption strategies, climate hazards, crop richness, high hills

\section{INTRODUCTION}

With changing global climate, agriculture is always at risk. Nepalese high hills have been observed and predicted as areas of rapid climate change inviting high uncertainty in crop production (Bhatt, 2015). Climatic variability such as rising temperatures, irregular monsoon, and changes in intensity and pattern of rainfall have been observed in Nepal affecting agricultural sector significantly (Ghimire et al, 2010). Magnitude of such risks has shown an inclining trend over the past few years. Given low development of the country with subsistence based, rain-fed dominant farming system and complex topography, Nepal is highly vulnerable to climatic variability and managing agricultural risk associated with climate change is particularly important.

To manage this risk, different strategies have been adopted. They include change in crop varieties and livestock breeds, management, and insurance. Crop diversification has been found building climate change resilience in small holder farms in Zimbabwe (Makate et al, 2016). Fisher and Surminski (2012) reported importance of public and private sector to ensure that climate change adaptation measures are adapted to address vulnerability. In the context of developing country, informal approaches such as savings, household buffer stocks, and community savings were important (World Bank 2011). Hazzel etal, 1986 reported use of fixed rentals, crop sharing, and other forms of leasing in India.

How locally available crop species are reacting to extreme weather events and what are existing adaptation strategies in Nepal Himalaya have aroused interest of climate experts, agricultural scientists and the governments around the globe. With this background this paper highlights how rich are genetic base of agricultural crops in those areas, what is the trend of extreme weather events, and how local farmers are coping with change in climatic pattern. This paper is mainly based on the information collected for the site selection for the project Integrating Traditional Crop

Corresponding author (Email: ynghimire@gmail.com),NARC,Khumaltar,Nepal 
Genetic Diversity into Technology: Using a Biodiversity Portfolio Approach to Buffer against Unpredictable Environmental Change in the Nepal Himalayas (Ghimire et al, 2014).

\section{OBJECTIVES}

The objectives of the study were to assess the diversity of crops and crop varieties in the high hills of Nepal, mapping extent of change in weather events over time, analyse impacts of such events in crop farming, and assess the adaptation practices used by the farmers.

\section{METHODOLOGY}

Eight keystone crops namely cold tolerant rice, finer millet, foxtail millet, prosomillet, barley, amaranthus, buckwheat and beans were identified for the site selection study for the project Integrating Traditional Crop Genetic Diversity into Technology: Using a Biodiversity Portfolio Approach to Buffer against Unpredictable Environmental Change in the Nepal Himalayas. Three districts namely Humla, Kaski and Soukhumbhu were selected from midwestern, western and eastern development regions of Nepal respectively as representative districts for Nepal high mountain agro-ecology from national level stakeholder meeting organized in Kathmandu and with the help of desktop review on the availability of biodiversity of keystone crops identified. One village from each of these districts was selected from district level stakeholder workshop organized in respective districts. A set of village selection criteria was discussed in district level stakeholder meetings and finalized. Chhipra VDC from Humla, Takashindu VDC from Solukhumbhu and Lumle VDC from Kaski were selected for the project implementation. The criteria used to select these VDCs included availability of important keystone crops, high agro-biodiversity of keystone crops, climatic variability, accessibility for intervention, a virgin area (distributive impact and ease in implementation), demonstrative effect (location importance), public interest (prior public content and potential participation in the project) and availability of mixed ethnic setup (social inclusion component). Focus Group Discussion (FGD) with the use of diversity analysis tools viz. four-cell analysis, noting traits of local crop genetic resources, and matrix ranking of crop varieties were conducted. It was supplemented by climatic hazards matrix preparation and seasonal calendar. A transect walk and direct observation of sites were also done to validate the information collected so far.

\section{RESULTS AND DISCUSSION}

This section summarises location of study sites, their economy, major crops, cropping patterns and food sufficiency status. Also highlighted are adoption status of major crops, change in the nature of hazards over time affecting crops, and local adaptation strategies.

\section{Description of study sites}

Solukhumbhu district lies between 27.20'N - 28.06' N latitude and 86.22' E - 87.03' E longitude and has a diversity of sub-tropical, temperate, cool temperate and alpine climate. The district spreads from 1500 masl to 8848 masl. Similarly, Humla district lies between 29. 35' -30 10' N latitude and $82.23^{\prime} \mathrm{E}-83^{\prime} 4^{\prime} \mathrm{E}$ and has a diversity of temperate, cool temperate and alpine climate. The district spreads from 1524 masl to 7337 masl. Kaski district lies between 28 6' N-28 36' N latitude and $83.40^{\prime} \mathrm{E}-84 \cdot 12^{\prime} \mathrm{E}$ longitude. Climate is similar to the climate of above districts. However, lower level elevation of $\mathbf{4 5 0}$ masl makes this district more intense in agriculture. The higher altitude level of the district is 7339 masl (Rimal and Rimal, 2006). The villages have diverse land uses ranging from snow clad high mountain areas to low lying river basin areas. Main land use types are forest, agricultural land and pasture. Among these uses, forest is dominant land use type in 
Takashindu and Humla, whereas Lumle has more areas under cultivation than areas under forest. The pasture covered areas is very small ranging from 1-3 per cent total land available in the Village Development Committee. The VDCs are characterized by diverse caste structure. Chhetri, Brahman and Dalits are major castes in Chhipra and Lumle, whereas, Sherpa, Tamang and Dalits are major castes in Takashindu. Population densities were 30, 72 and 108 per square kilometre, repectively and this is low compared to other hill and terai VDCs spread in different clusters.

These VDCs have acute food shortage. Agricultural productions from these VDCs are barely enough to support their food needs for more than 20 per cent of the village population. Percentage of food sufficient households in the village counts less than 10 per cent. The food needs are met through importing from adjoining market centers. Potato, wheat, maize, barley and bean are four most important food security crops grown in Chhipra and Takashindu, and rice, wheat, maize and millet are most important for Lumle. Major livelihood strategies in the villages were agriculture and livestock keeping, Hotel/Business, office, labor and industry. Agriculture is the dominant sector in all these villages. In Takashindu, due to its location in the Khumjung Trek, hotel business is also spreading along the route.

\section{Existing crops and major cropping patterns}

Along with keystone crops, many vegetables are also grown including pumpkin, colocasia, tomato, gourd, garlic, onion, etc. Similarly, spices like coriander, turmeric, ginger, etc. Among fruits, apple, peach, and plum are common in Chhipra and Takashindu, whereas, orange, peach, plum and citrus are major fruits in Lumle. The village economy of Chhipra and Takashindu are also supported by the collection and sale of herbs including yarsagumba, paanchaule, attis, ghodamarchaa, etc. Regarding livestock, buffalo, cattle and sheep/goat are kept. Crops are grown in three major domains: lowland khet, upland khet and pakho. Cropping patterns in lowland khet are irrigated rice based patterns. Important second crops are wheat and barley. Chhipra and Takashindu have only a single crop of rice in rice land. Cropping pattern in Lumle is more intense with second crop of either wheat or barley. In upland khet, upland rice is grown which is followed either by barley, or wheat, or lentil, or pea, or soybeans, etc in either one-year or two-year pattern.

\section{Adoption and social preference of crops varieties}

Four Cell analyses show the condition of crops or variety in community level. Varieties for food security or for the market or with multiple use values tend to be cultivated in large areas by many households are kept in the first room. Second room includes landraces cultivated for sociocultural (traditions, religious rituals, food culture) purposes which are grown in small areas by many households. Third room has varieties with specific adaptations traits (such as cultivars adapted to swampy lands, poor soil fertility, drought, shade etc.) are grown in large areas by few households. Similarly, fourth rooms' keeps varieties with specific use or limited use as valued by particular families and are grown in small areas by a few households. Figermillet, rice, barley, maize and beans come in cell one indicating high level of adoption of these crops, whereas, horse gram, lentil, and vegetables and fruit crops come in Cell Four. The analysis of fingermillet variety reveals their adoption level by area and number of households growing. The pattern of adoption of fingermillet is not distinct among sites. Similarly, rice varieties Dhoinala, Darmali, Reksali, and Kathe have been grown by many households in large areas. Chomorong, Kalo Dhatulao, Marsi, Gudura, Tauli, Sinjali, etc. are grown by few households in small areas only. Bean varieties like Jumli, Kalo, thulo seto, thulo pangre, Kentuki wonder, Bhatte, offseason, Kathe, Maki, etc. are grown by many households in larger area. However, Rato, Pahelo, Sano Kalo, Sano pangre, Ghiu simi bean varieties are grown in small areas by few households. 
Matrix ranking shows that fingermillet varieties like Riule, Tyanse, and aankhe are most preferred fingermillet varieties in Chhipra, paudure, mannsire, and seto are preffered in Takashindu. Similarly, Dalle, Archale, and Bhachuwa are preferred in Lumle based on overall ranking and prioritization. In Takashindu high altitude areas, Paudure and Mansire, and Kalo are preferred in riverbasin areas of the VDC. Overall rating based on farmers' criteria, Channanth, Kalo dhan and Kalo Mari were top among other varieties in Chhipra. In Lumle, Kalo patle, manamure, and Reksali are better varieties. Upland rice varieties namely, Ratanpuro, Khachya, and Dhoi Nayala are ranked at the top in Chhipra. Lumle-2 and Chomorong are most important vaieties in Lumle. Takashindu farmers could not assignweights to the rice varieties. In Chhipra, bean varieties namely Jumli, Kato and Seto are most preferred. Thulo seto, thulo chirbire are best varieties in Takashindu; Kentuki wonder, four season and Ghandruke are best performers in Lumle.

\section{Climate change effects in agriculture and adaptation strategies}

Behaviour of major seasonal hazards has been assessed over time in each study village. Also, analysed were the existing adaptation strategies.

\section{Climate change effects in agriculture and adaptation strategies in Chhipra}

Table 1: Seasonal hazard calendar of Chhipra

\begin{tabular}{|c|c|c|c|c|c|c|c|c|c|c|c|c|}
\hline $\begin{array}{c}\text { Major } \\
\text { climate } \\
\text { risks }\end{array}$ & Baisakh & Jestha & Ashadh & Sharawan & Bhadra & Ashoj & Kartik & Marga & Poush & Magh & Falgun & Chaitra \\
\hline \multirow{2}{*}{ Drought } & & & & & & & & & & & & \\
\hline & -2 & $E$ & - & & & & & & & & & \\
\hline \multirow{2}{*}{ Hailstone } & & & & & & & & & & & & \\
\hline & & & & & & & & -2 & -2 & - & & \\
\hline \multirow{2}{*}{$\begin{array}{c}\text { High } \\
\text { Rainfall }\end{array}$} & & & & & & & & & & & & \\
\hline & & & - & -2 & $E-$ & & & & & & & \\
\hline
\end{tabular}

Note: Solid line: Before B.S. 2000; Dotted line: present situation (B.S. 2014)

Drought, snowfall, low rainfall and frost/chilling are taken as the climate change parameters in the selected villages (table 2). Huge snowfall occurred in 2047 Jestha. One big drought was observed in 2054 and 2065, huge floods observed in 2060 and 2062. The effects of these manifestations are seen in principal crops, livestock animals and fruits. Buckwheat and legumes are reported to have smaller impacts of drought while, rice, millets, barley and domestic animals are most severely affected by these events. Snowfall effect is most severe in barley and wheat. However, chilling/frost does little harm than other hazards in the villages. Seasonal hazard calendar has been presented which shows the situation 15 years ago and present time compared in terms of agricultural practices and changes in occurrences of hazards.

Table 2: Hazard matrix: scale 0-3 (Small effect gets 0 or 1 while increasing effect gets more scale)

\begin{tabular}{|l|c|c|c|c|}
\hline \multicolumn{1}{|c|}{ Crops } & Drought & Snowfall & $\begin{array}{c}\text { Low } \\
\text { rainfall }\end{array}$ & Chilling/Frost \\
\hline Rice & 3 & 1 & 3 & 1 \\
\hline Potato & 2 & 0 & 0 & 0 \\
\hline Buck wheat & 1 & 0 & 0 & 1 \\
\hline Finger millet & 3 & $\begin{array}{c}\text { 2 (insect pest attack } \\
\text { increases in low snow fall) }\end{array}$ & 2 & 1 \\
\hline
\end{tabular}




\begin{tabular}{|l|c|c|c|c|}
\hline Proso millet & 2 & 1 & 1 & 0 \\
\hline Foxtail millet & 3 & 2 & 2 & 1 \\
\hline Amaranthus & 2 & 1 & 2 & 0 \\
\hline Barley/ naked barley & 3 & 3 & 2 & 1 \\
\hline Wheat & 1 & 3 & $1 / 1 / 1$ & $0 / 0 / 0$ \\
\hline Soyabean, beans, horsegram & $1 / 2 / 1$ & $0 / 0 / 0$ & 1 & 2 \\
\hline $\begin{array}{l}\text { Livestock- cows, } \\
\text { buffalo, goat, sheep }\end{array}$ & 3 & $\begin{array}{c}\text { 1 but grass production } \\
\text { decreases }\end{array}$ & 1 & 0 \\
\hline Apple, Peach, Khurpani & 2 & 0 & 1 \\
\hline
\end{tabular}

Adaptation strategies against drought for rice, millet and barley are presented in table 3. Farmers cannot transplant rice, fingermillet and foxtail millet, delay in rainfall in planting season. Drought in flowering stage causes sterility. If rain is further delayed, farmers even cancel transplanting. Barley and naked barley plant will be dried. Adaptation strategies include i) buckwheat, wheat and bean planted cancelling rice and fingermillet, and foxtail millet planting, ii) Manual irrigating from water sources and iii) if barley and naked barley crops dry up, farmers wait for next season planting.

Table 3: Adaptation practices

\begin{tabular}{lll}
\hline \multicolumn{1}{c}{ Crops } & \multicolumn{1}{c}{ Effects } & \multicolumn{1}{c}{ Adaptation Strategies } \\
\hline Rice & - Transplanting cancelled & - Buck-wheat and beans planted in July \\
& - Sterility & $\begin{array}{l}\text { - Harvest only straw and taking minimum } \\
\text { production }\end{array}$ \\
Finger millet & - Transplanting cancelled & $\begin{array}{l}\text { Buck-wheat and beans planted but few } \\
\text { households plant FM by carrying water } \\
\text { from resources }\end{array}$ \\
Foxtailmillet & - Transplanting cancelled & - Buck-wheat and beans planted \\
Naked barley/Barley & - Drying of plants & - Keep fallow until next season
\end{tabular}

Climate change effects in agriculture and adaptation practices in Takashindu

Table 4: Seasonal hazard calendar of Takashindu

\begin{tabular}{|c|c|c|c|c|c|c|c|c|c|c|c|c|}
\hline $\begin{array}{c}\text { Major } \\
\text { climate } \\
\text { risks }\end{array}$ & Baisakh & Jestha & Ashadh & Sharawan & Bhadra & Ashoj & Kartik & Marga & Poush & Magh & Falgun & Chaitra \\
\hline Drought & - & -1 & -- & & & & & & & & & \\
\hline Hailstone & & & & & & & & & & & & \\
\hline & 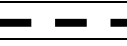 & -0 & & & & & & & & & & \\
\hline Frost & & & & & & & & 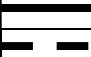 & - & $\bar{E}$ & $=$ & \\
\hline
\end{tabular}

Note: Solid line: Before B.S. 2000; Dotted line: present situation (B.S. 2014) 
Heavy rainfall, frost, drought and snowfall are major climate hazards in Takashindu village too (table 5). Bean, potato, maize and wheat are severely affected by high intensity rainfall. Frost and snowfall damage crucifer vegetables. Barley, potato and crucifers also are moderately affected by drought. Seasonal hazard calendar has been presented which shows the situation in 15 years period and present time compared in terms of agricultural practices and changes in occurrences of hazards.

Table 5: Hazard matrix: scale 0-3 (Small effect gets 0 or 1 while increasing effect gets higher scale)

\begin{tabular}{lcccc}
\hline \multicolumn{1}{c}{ Crops } & Drought & Snowfall & Low rainfall & Chilling/Frost \\
\hline Bean & 2 & 0 & 0 & 0 \\
Barley/Naked Barley & 0 & 0 & 1 & 0 \\
Fingermillet & 1 & 0 & 0 & 0 \\
Buckwheat & 0 & 0 & 0 & 0 \\
Potato & 2 & 0 & 1 & 0 \\
Wheat & 2 & 0 & 0 & 0 \\
Maize & 2 & 0 & 0 & 0 \\
Cauli flower/Cabbage/board leaf mustard & 0 & 2 & 1 & 3 \\
\hline
\end{tabular}

Climate change effects in agriculture and farmers' adaptation practices in Takashindu have been presented in table 6 . Heavy rainfall affects fertilization in bean and fingermillet and grain is not formed. With this hazard, wheat grains sprout in the field, maize plant lodge causing yield damages to these plants.

Table 6: Farmers' adaptation practices against heavy rainfall in Takashindu

\begin{tabular}{lll}
\hline Crops & Effects & Adaptation Practices \\
\hline Bean & - Damage of flower & - No action taken \\
Fingermillet & - No grain setting & - No grain setting \\
Potato & - Drying plants ( blight disease) & - No action taken \\
Wheat & - Germination at the panicle & - No action taken \\
Maize & - Lodging & - No action taken \\
& - low yield & \\
\hline
\end{tabular}

\subsection{Climate change effects in agriculture and adaptation practices in Lumle}

Table 7: Seasonal hazard calendar of Lumle

\begin{tabular}{|c|c|c|c|c|c|c|c|c|c|c|c|c|}
\hline $\begin{array}{c}\text { Major } \\
\text { climate } \\
\text { risks }\end{array}$ & Baisakh & Jestha & Ashadh & Sharawan & Bhadra & Ashoj & Kartik & Marga & Poush & Magh & Falgun & Chaitra \\
\hline \multirow{2}{*}{ Snowfall } & & & & & & & & & & & & \\
\hline
\end{tabular}




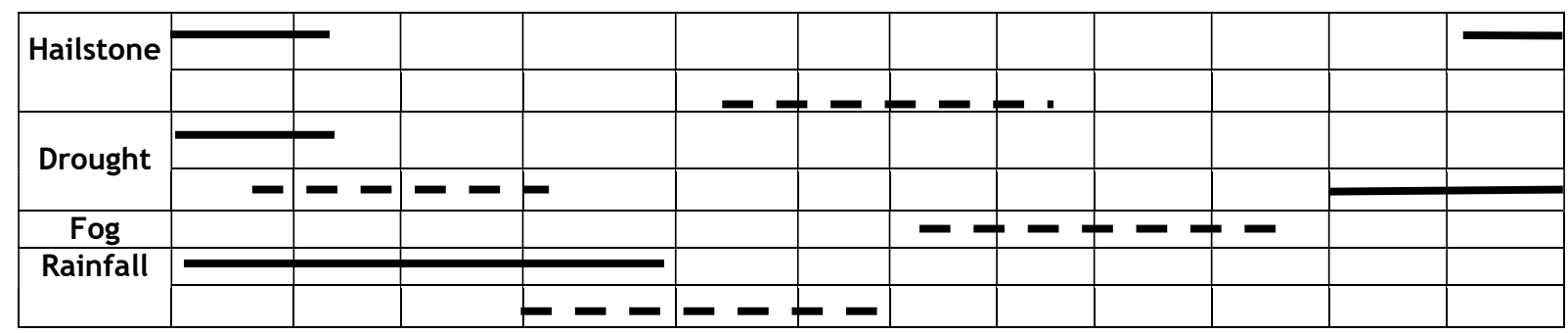

Note: Solid line: Before B.S. 2000; Dotted line: present situation (B.S. 2014)

Major shift in climate and cropping behaviour in Lumle have been given in table 7. Drought, snowfall, low rainfall, high rainfall, hailstone, frost/chilling and fog are main the climate change manifestations in Lumle (table 8). Huge snowfall occurred in 2063, causing heavy loss of vegetables, mustard and wheat in the village. Hailstone of 2068 damaged rice crop at harvest time. Lightening of 2063 and 2067 Destroy of power houses destroyed houses, livestock, man and crops and other plants. Forest fire outbreak in 2066 took lives of many wild animals. Seasonal hazard calendar has been presented which shows the situation 15 years ago and present time compared in terms of agricultural practices and changes in occurrences of hazards.

Table 8: Hazard matrix: scale 0-3 (Small effect gets 0 or 1 while increasing effect gets more scale)

\begin{tabular}{lccccccc}
\hline \multicolumn{1}{c}{ Crops } & $\begin{array}{c}\text { Low } \\
\text { rainfall }\end{array}$ & $\begin{array}{c}\text { More } \\
\text { rainfall }\end{array}$ & Snowfall & $\begin{array}{c}\text { High cold/ } \\
\text { Frost }\end{array}$ & $\begin{array}{c}\text { Hail } \\
\text { stone }\end{array}$ & Drought & Fog \\
\hline Rice & 3 & 1 & 0 & 0 & 3 & 2 & 2 \\
Maize & 1 & 3 & 0 & 0 & 3 & 1 & 0 \\
Wheat/Barley/NBarley & 2 & 0 & 0 & 0 & 3 & 3 & 0 \\
Potato & 2 & 3 & 3 & 2 & 3 & 2 & 3 \\
Amaranthus & 0 & 0 & 0 & 0 & 3 & 0 & 0 \\
Fingermillet & 2 & 2 & 0 & 0 & 2 & 2 & 0 \\
Soyabean & 0 & 0 & 0 & 0 & 2 & 0 & 0 \\
Beans & 0 & 1 & 1 & 0 & 2 & 2 & 0 \\
Vegetables & 1 & 2 & 1 & 1 & 3 & 2 & 1 \\
Livestock-Cows, buffalo & 0 & 2 & 2 & 2 & 1 & 2 & 1 \\
Goat, sheep & 0 & 3 & 2 & 2 & 1 & 2 & 1 \\
Chicken & 0 & 0 & 0 & 0 & 0 & 0 & 0 \\
\hline
\end{tabular}

Climate change effects in agriculture in Lumle have been presented in table 8. Mainly rice is affected by low rainfall, maize, potato, goat and sheep by heavy rainfall. Hailstone is devastating to all the crops plants. Wheat, barley are affected by drought. Fog is detrimental especially to potato crop which helps develop late blight the field. Farmers' adaptation practices against drought in Lumle has been given in table 9. Technology change and late planting are important practices farmers are adopting. 
Table 9: Farmers' adaptation practices against drought in Lumle

\begin{tabular}{lll}
\hline Crops & Effects & Adaptation Strategies \\
\hline Rice & - No timely transplantation & - Variety change \\
& & - Late transplanting \\
Fingermillet & - No timely transplantation & - Variety change \\
Vegetables & - Low production & - Sprinkle and drip irrigation \\
Potato & - Insect and pest attack & - No action \\
\hline
\end{tabular}

\section{THREATS AND BARRIERS TO AGRO-BIODIVERSITY CONSERVATION}

Socioeconomic threats and barriers to agro-biodiversity conservation were found as follows:

- Finermillet, foxtailmillet, and prosomillet are minor crops for Nepal. These crops are not considered holy food in Nepalese society.

- Elitism in Nepal- 'Rice' is considered to be an elite food, even in places where it can't be grown, equally disparaging towards those who cannot eat them. Therefore, growing other crops, offers less incentive.

- Inadequate research in keystone crops except rice (NARC research highlights) has offered less incentive to growing these crops.

- Food subsidies and other forms of external support have created a state of dependency, stifling local initiative and reducing reliance on local resources (Roy et al, 2009).

- Less attraction to local crops due to development of tourism without linking it to use value of available diverse local foods in high hills where farming is less preferred.

- Push of market in favor of highly marketed crops has abandoned local crops and varieties.

\section{CONCLUSION}

High hill agriculture in Nepal is characterised by high agrobiodiversity. Incidences of Weather hazards have been found increasing with the change in global climate change posing threats to crop farming and local livelihoods. Farmers have developed adaptation strategies to cope with changing climate. Tourism, low social value attached to traditional crops, inadequate research, and food subsidy and other forms of external support have also been identified as the threat to agrobiodiversity conservation. Promotion of agro-tourism, identifying crop varieties tolerant to extreme weather events and their promotion through technology development and value addition have been suggested to combat climate change effects in high hill agriculture in the country.

\section{ACKNOWLEDGEMENT}

Financial support by the GEF availed through LI-BIRD is highly appreciated. Also, district stakeholders of Humla, Kaski, and Solukhumbhu districts have been acknowledged for their support 
in selecting representative villages. The authors are also thankful to farmers for providing information through Focus Group Discussions.

\section{REFERENCES}

Bhatt, J.C., Arukumar, R. and Stanley, J., 2015. Climate Change and Hill Agriculture inNorthwest Himalaya.Climate Change Modelling, Planning and Policy for Agriculture, pp 167-178.

Solukhumbhu District Development Office., 2012. District Profile of Solukhumbhu. District Development Office, Salleri, Solukhumbhu (in Nepali).

Humla District Development Office., 2012. District profile of Humla. District Development Office, Simkot, Humla (in Nepali).

Fisher, S., and Surminski, S., 2012. The roles of public and private actors in the governance of adaptation: the case of agricultural insurance in India. Centre for Climate Change Economics and Policy, Working Paper No. 102; Munich Re Programme Technical Paper No. 15, Grantham; and Research Institute on Climate Change and the Environment Working Paper No. 89

Ghimire, Y. N., Timsina, K. and Gauchan, D., 2010. Risk Management in Agriculture: Globalexperiences and lessons for Nepal, DOI: 10.13140/RG.2.1.2670.4882.

Ghimire, Y. N.; Rana, R. B., Ale, S., Poudel, I., and Tamang, B. B., 2014. Site Selection Report. Integrating Traditional Crop Genetic Diversity into Technology: Using a Biodiversity Portfolio Approach to Buffer against Unpredictable Environmental Change in the Nepal Himalayas.

Hazell, P., Pomareda, C., and Valdes, A. (Eds).,1986. Crop Insurance for Agricultural Development. Published for the International Food Policy Research Institute, The Johns Hopkins University Press Baltimore and London

Lumle Village Development Committee., 2012. VDC profile of Lumle. Lumle Village Development Committee, Lumle.

Makate, C., Wang, R., Makate, M., and Mango, N., 2016. Crop diversification and livelihoods of smallholder farmers in Zimbabwe: adaptive management for environmental change. Springerplus. 2016; 5(1): 1135. Published online 2016 Jul 19. doi: 10.1186/s40064-016-2802-4 PMCID: PMC4951382

Roy, R., Schmidt-Vogt, D., and Myrholt, O., 2009. “Humla Development Initiatives” for Better Livelihoods in the Face of Isolation and Conflict.Mountain Research and Development 29(3):211-219. 2009. doi: http://dx.doi.org/10.1659/mrd.00026.

World Bank., 2011. Weather Index Insurance for Agriculture: Guidance for Development Practitioners. Agriculture and Rural Development Discussion Paper 50. World Bank. 